\title{
Seed abortion in the sexual counterpart of Brachiaria brizantha apomicts (Poaceae)
}

\author{
Ana Claudia Guerra Araujo · Rosana Falcão • \\ Vera Tavares de Campos Carneiro
}

Received: 22 June 2006/Accepted: 10 March 2007/Published online: 3 May 2007

(C) Springer-Verlag 2007

\begin{abstract}
Gametophytic organization, fertilization and reproductive success are described for the fertile diploid Brachiaria brizantha accession BRA-002747 which is being raised for use in Brachiaria breeding programs, as well as to understand and control of apomixis in this genus. The current paper reports on reproductive biology and analysis of seed set in field experiments during three consecutive years. Unsuccessful seed production in this plant is believed to correlate with early inbreeding depression, based on the reproductive features analyzed. Caryopsis development was observed using differential interference contrast microscopy with seed set determined by the number of self- and open-pollinated pistils that fully developed into viable seeds. Developing and mature female and male gametophytes were observed in the context of flower phenology, morphology and anthesis patterns. Pollen viability was determined by acetocarmine staining and by observation of germination in vivo, which was also used to observe pollen tube/pistil interaction. Although normal development was observed in floral structures, anthesis and gametophytes, seed set was low, with 2 and $6 \%$ in self- and open-pollination, respectively, producing seed. Variations observed in the female organs, such as the presence of a hermaphrodite flower in 50\% of the inferior floscules and the presence of multiple embryo sacs of the Polygonum type within the same ovule in $15 \%$ of the pistils, are not
\end{abstract}

Communicated by Scott Russell.

A. C. G. Araujo $(\varangle) \cdot$ R. Falcão ·

Vera Tavares de CamposCarneiro

Embrapa Genetic Resources and Biotechnology,

Parque Estação Biológica, Av. W/5 Norte (Final),

P.O. Box 02372, 70770-900 Brasilia, DF, Brazil

e-mail: guerra@cenargen.embrapa.br related to low fertility. The majority of pollen grains are viable, in spite of the reduced number of pollen tubes within the style and ovary carpel, and a developing caryopsis was observed in $70 \%$ of self-pollinated pistils, indicating successful double fertilization from 2 days after anthesis (DAA). Nevertheless, abortion gradually increased from 2 until 7 DAA and remains elevated until 12 DAA, when caryopsis maturity is achieved. These data confirm low seed set in this accession and indicate that low fertility is not a consequence of abnormalities, either in the floral or gamete structures, or pollen tube rejection, but most likely a consequence of inbreeding depression.

Keywords Embryogenesis - Embryo sac - Fertilization · Gametophyte $\cdot$ Seed set

\section{Introduction}

The genus Brachiaria (Trin.) Griseb. belongs to the family Poaceae and comprises around 100 species (Renvoize et al. 1996, http://www.ipni.org/index.html). A number of Brachiaria species are cultivated as forage grasses in tropical areas (Keller-Grein et al. 1996) but few reproduce sexually. A Brachiaria collection was established at the International Center for Tropical Agriculture-CIAT, Colombia and duplicated at Embrapa, Brazil (Valle 1990). Brachiaria accessions are mostly polyploids that reproduce through apomixis, whereas the diploid accessions are sexual (Valle 1986, 1990; Valle and Savidan 1996). Apomixis, as an asexual mode of seed-based reproduction produces progeny that are genetically identical to the mother plant (Asker and Jerling 1992).

Among the 275 B. brizantha accessions of the collection, only one accession has been identified to date as 
diploid, BRA-002747 (Carnahan and Hill 1958; Valle and Glienke 1991; Penteado et al. 2000).

The development of BRA-002747 megagametophytes displayed normal differentiation of the megaspore mother cell within nucellar tissue and formation of megaspores (tetrad), but this is followed by degeneration, which leaves one surviving megaspore, chalazally located, which developed into an embryo sac of the Polygonum type, composed of egg cell, two synergids, a bi-nucleated central cell and six antipodal cells (Valle and Glienke 1991, Valle and Savidan 1996; Araujo et al. 2000, 2005a). The microgametophyte displays regular meiotic patterns, exhibiting mostly bivalent associations (Valle and Savidan 1996; Mendes-Bonato et al. 2002). This accession has been widely employed in comparative genetic, molecular (Rodrigues et al. 2003, Alves et al. 2007) and cellular studies (Araujo et al. 2000) with a number of some apomictic counterparts and also used to obtain induced tetraploid sexual plants (Pinheiro et al. 2000; Araujo et al. 2005a).

Diploid sexual accessions of Brachiaria are generally considered to have low fertility (Valle and Savidan 1996), and the reasons are unclear. Reduced fruit/seed set in flowering plants is mainly related to physiological selfincompatibility (SI) and early-acting inbreeding depression (Sage et al., 1999). SI is present in approximately one-half of the angiosperms (East 1940), and in grasses it appears to be prevalent (Baumann et al. 2000). SI can be detected at the stigmatic or stylar level as a self-pollen tube/pistil reaction, or later with rejection of the selfed pistil, despite the fact that self-pollen tubes grow to the ovules (Seavey and Bawa 1986; Gibbs et al. 2004).

The SI was reported by Gustafsson (1946-1947) and Stebbins (1950) in all the reviewed sexual counterparts of apomictic plants, including grasses such as Brachiaria, and it appears to be prevalent as sporophytic self-incompatibility, with a rapid rejection reaction of self-pollen tubes at the stigmatic level (Lundqvist 1964, reviewed by Ngendahayo et al. 1988; Valle and Savidan 1996). However, it has not been determined whether this mechanism is common in the whole family (reviewed by Baumann et al. 2000), as there are many species that are predominantly cross-fertilizing and frequently display inbreeding depression (Bush and Barret 1993). Further studies on the breeding system were performed only with $B$. ruziziensis, for which apomictic counterparts have not been identified so far. The observation of rejection sites in the stigma and style and the low rates of selfed seeds, varying from 0.49 to $7.20 \%$, indicated a preferentially allogamous system, although slight self-compatibility was also detected in the diploid, in the induced sexual tetraploid and sexual hybrids of this species (reviewed by Ngendahayo et al. 1988; Lutts et al. 1991).
Considering the important role of this single sexual diploid accession of $B$. brizantha to the improved understanding of apomixis and to the development of new tools for breeding programs, the present study evaluated BRA002747 seed production and its main reproductive characteristics over three consecutive years. The low seed set is quantitatively reported. Data suggest that low seed set is not associated with abnormalities in the reproductive development or fertilization of pistils, but with the abortion of caryopsis from 2 DAA.

\section{Materials and methods}

\section{Plant material}

Brachiaria brizantha diploid $(2 n=2 \mathrm{x}=18)$ sexual accession BRA-002747 from the Embrapa germplasm collection (Embrapa Beef Cattle, Campo Grande, MS, Brazil) was duplicated and vegetatively propagated in the Brachiaria experimental field maintained at Embrapa Genetic Resources and Biotechnology (Cenargen) BrasiliaDF, Brazil where tests were performed during the 20022004 growing seasons.

\section{Floral biology}

Flower phenology, the number of racemes per inflorescence axis $(n=100)$, and the number of spikelets per raceme $(n=150)$ were determined. The morphology of the two flowers of the spikelet, the hermaphrodite within the superior floscule and the staminate or hermaphrodite flower within the inferior floscule was described. Anthesis was observed in all flowers of the superior floscule of the spikelet of five distinct racemes in 10 individuals of the genotype BRA-002747. The length of the stigma with respect to receptivity was determined using flowers collected from racemes ( $n=5$ at each sample period) $1 \mathrm{~h}$ after stigma exertion and thereafter at hourly intervals up to $10 \mathrm{~h}$, and then after $22,24,30$ and $48 \mathrm{~h}$. Pistils were isolated and immediately treated with $3 \%$ hydrogen peroxide. The presence of bubbles in the stigmas, corresponding to the presence of peroxidase enzyme activity was assayed using a Zeiss SV16 stereomicroscope (Oberkochen, Germany) to reflect stigma receptivity and the viability of stigmatic cells.

Developing and mature female gametophytes

Pistils were collected daily from 5 days before anthesis initiation to the day of anthesis and classified as stages I, II, III and IV, based on the length and stigma morphology 
according to Araujo et al. (2000). Stages I and II corresponded to megasporogenesis, and stages III and IV corresponded to megagametogenesis. Stage I included pistils approximately $0.48 \mathrm{~mm}$ long with primordial stigmas; stage II, $1.38 \mathrm{~mm}$ long containing elongated primordial stylodia; stage III, $2.36 \mathrm{~mm}$ long with elongated stylodia and hairy stigmas; and stage IV with pistils $3.63 \mathrm{~mm}$ long with red hairy stigmas. Ovules were isolated from pistils at stages I-IV and fixed in a FAA mixture (40\% formaldehyde: glacial acetic acid: 50\% ethanol 5:5:90, v/v/v) for $24 \mathrm{~h}$ at $4^{\circ} \mathrm{C}$, dehydrated in an ethanol series $(70,80,90,95$ and $100 \%$ ) and embedded in JB4 ${ }^{\circledR}$ (Polysciences, USA) plastic resin. Semi-thin sections $(2-4 \mu \mathrm{m}$ thick) were obtained and stained with methylene blue-basic fuchsin for morphological assessment. Observations were performed using a bright field Zeiss Axiophot photomicroscope (Oberkochen, Germany).

Three hundred mature ovules were isolated from superior flower pistils labeled at anthesis initiation, fixed in FAA solution for $24 \mathrm{~h}$ at $4{ }^{\circ} \mathrm{C}$, dehydrated in ethanol and cleared in solutions containing xylene:methylsalicylate at increasing concentrations from 1:1 (v/v) until pure methylsalicylate (modified after Young et al. 1979). Cleared ovules were whole-mounted, with structure, position and embryo sac number observed using differential interference contrast (DIC) on a Zeiss Axiophot photomicroscope.

Pollen development, stainability and in vivo germination

Developing male gametophytes were obtained from anthers and classified according to the characteristics of the associated pistils described earlier (stage I, II, III or IV). Anthers at stage I were associated with pistils classified as stage I and thereon for all other stages. Fast green and safranin stained sections (5-6 $\mu \mathrm{m}$ thick) of anthers were obtained after fixation in FAA, dehydration and embedding in Paraplast ${ }^{\circledR}$. Other developing anthers were fixed in $70 \%$ (v/v) ethanol for $24 \mathrm{~h}$, squashed on histological slides and stained with propione carmine $2 \%$ solution (Fukui and Nakayama 1996). Pollen development was observed using DIC or phase contrast microscopy using a Zeiss Axiophot photomicroscope. To estimate pollen viability, approximately 400 pollen grains were isolated from anthers of both flowers of the spikelet prior to anthesis, fixed in ethanol $70 \%(\mathrm{v} / \mathrm{v})$ for $24 \mathrm{~h}$ and stained with propione carmine solution (Fukui and Nakayama 1996). Observations were conducted using a phase contrast Zeiss Axiophot microscope and the number of stained pollen grains determined.

To confirm viability of pollen grains in vivo and to observe the pollen-pistil interactions, 120 superior pistils were emasculated and self-pollinated prior to anthesis initiation and labeled with a color permanent marker in the field. Labeled pistils were isolated 2, 4.5, 6.5, 8, 9, 11, 24, 26, 30, 32 and $48 \mathrm{~h}$ after pollination (HAP), 10 pistils at each period. Pistils were fixed in ethanol $70 \%(\mathrm{v} / \mathrm{v})$ for $12 \mathrm{~h}$ at $4^{\circ} \mathrm{C}$, washed in ethanol:acetic acid $(3: 1, \mathrm{v} / \mathrm{v})$ for $1 \mathrm{~h}$ at room temperature and stained with aniline blue (Martin 1959). The number of pollen grains adhered to stigmas was determined as well as the number and pathways taken by growing pollen tubes observed using fluorescence microscopy.

\section{Embryogenesis and caryopsis abortion}

Approximately 1,500 flowers were labeled at the start of anthesis using a color permanent marker. Labeled racemes were bagged in paper envelopes on the following day, under the assumption that open-pollination had occurred the previous day in the majority of the flowers. Envelopes were collected daily and 120 labeled flowers pooled from the first day until 12 days after anthesis initiation (DAA), when caryopsis maturity is achieved. The number of abscised flowers within the envelopes was counted. Flowers still attached to racemes had their pistils isolated, fixed in FAA solution, dehydrated in ethanol and cleared with xylene and methylsalicilate. Viable caryopses were counted and observed using DIC microscopy to detect the presence and condition of embryo and endosperm. The number of aborted caryopses was calculated based on observations of collapsed, shrunken embryo sacs and ovules with deposits of oxalate crystals.

Some cleared caryopses with viable ovules and embryo sacs containing developing embryo were isolated and embedded in Paraplast ${ }^{\circledR}$ (Polysciences, USA) after three washes in $100 \%$ ethanol for $1 \mathrm{~h}$ and three washes in xylene for another hour. Sections $(8-10 \mu \mathrm{m}$ thick) were stained with safranin-fast green.

\section{Selfed seed set}

Approximately 700 flowers were labeled with a color permanent marker, hand-emasculated prior to onset of anthesis and then pollinated with the pollen of other flowers from the same plant. Racemes were immediately bagged in paper envelopes and harvested 12 days after self-pollination (DAP). Another 3,000 flowers labeled at anthesis onset were bagged and harvested 12 DAA. Once again, open-pollination, when it occurred, was most likely to be self-pollination, although deposition and germination of different pollens at a low rate could not be ruled out. Seed set rates were determined based on the number of labeled flowers and the number of full, filled caryopses obtained. 


\section{Results}

\section{Floral biology}

The number of racemes varied from 6 to 13 and the number of spikelets per raceme from 10 to 46 , both depending on the raceme length and position along the inflorescence axis. The inflorescence was of the panicle type. Spikelets were uniseriate, placed on one side of the raceme and attached by a pedicel (Fig. 1a).

Spikelets were elliptical-oblong, dorsally elongated and composed of one superior and one inferior floscule (Fig. 1b). Each superior floscule comprised one hermaphrodite flower, whereas the inferior floscule showed dissimilarity: one-half showed a staminate or sterile (empty) flower while the remaining showed a hermaphrodite flower (Fig. 1c). Hermaphrodite flowers contained three stamens, long filaments, three bilocular anthers, a unilocular uniovulated ovary and a stylodium with two branched and feathered stigmas and a short style (Fig. 1d).

Flowering occurred yearly from the second week of April until late June, with a flowering peak in May. The average temperature during this period was $21^{\circ} \mathrm{C}$, varying from 14 to $26^{\circ} \mathrm{C}$ during the day. Day length was approximately $12 \mathrm{~h}$, and precipitation rates varied from $124 \mathrm{~mm}$ in April to $41 \mathrm{~mm}$ in June (http://www.br.weather.com/ weather/local/BRXX0043).

Approximately $80 \%$ of the flowers in superior floscules of the racemes entered anthesis at around 8:00 a.m. Anthesis commenced in flowers situated in the middle of the raceme, followed by those in the apical region and finally by those at the base of the raceme 4 DAA of the first flowers. Anther dehiscence occurred during the first hour after the onset of anthesis in $93 \%$ of the flowers.

Peroxidase activity in living stigmas of flowers stored in the lab was observed from anthesis until $6 \mathrm{~h}$ after anthesis initiation, decreasing thereafter, and absent at $24 \mathrm{~h}$ after the start of anthesis. In the field, stigmas were dry 10-12 h after anthesis.

\section{Developing and mature female gametophytes}

As previously described (Araujo et al. 2000), ovules at stages I and II were atropically positioned and showed

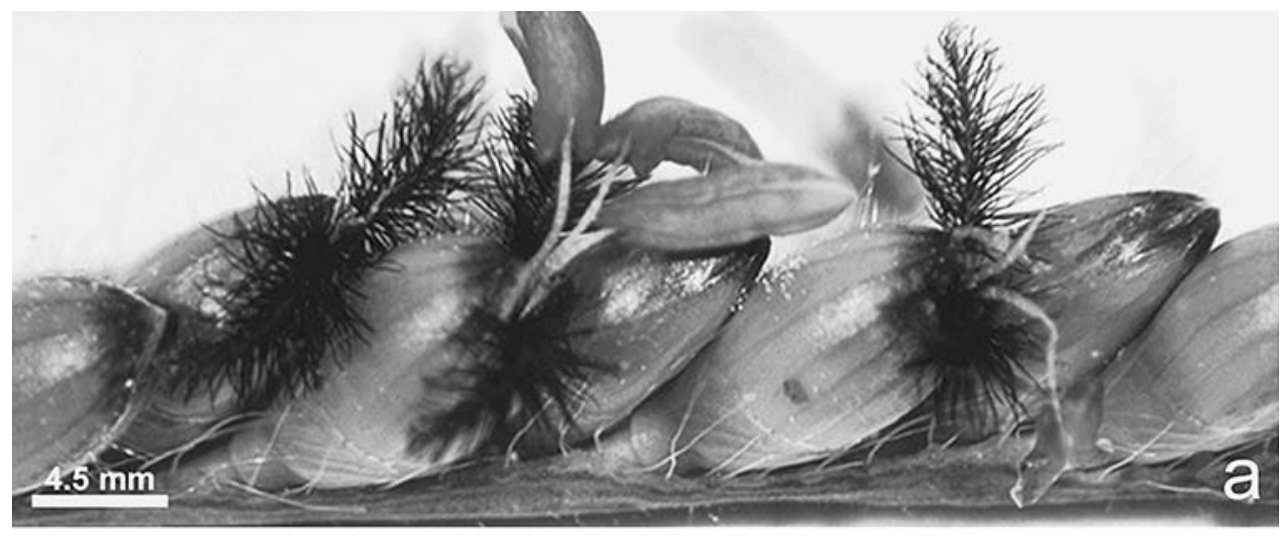

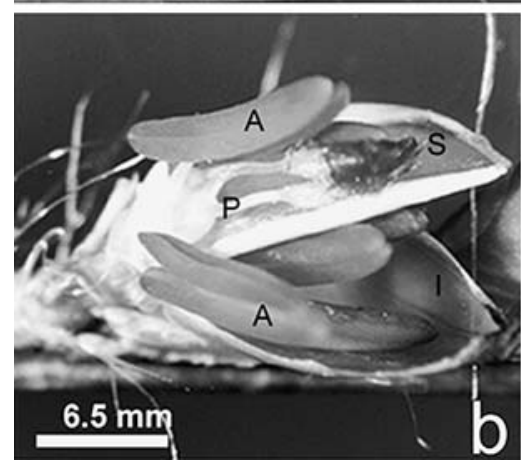
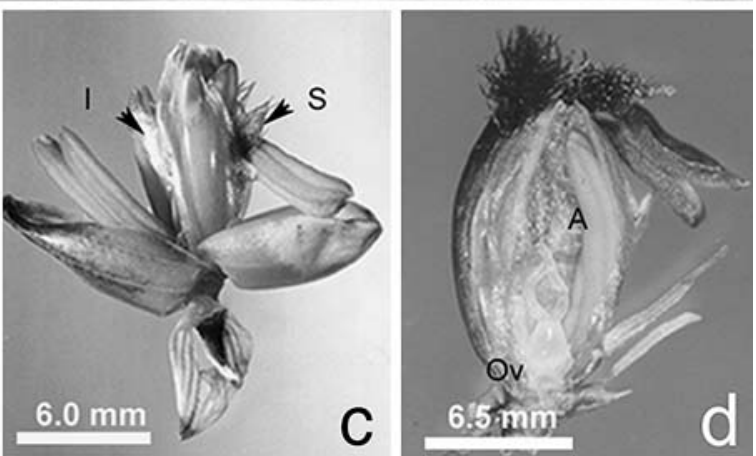

Fig. 1 Brachiaria brizantha diploid sexual accession, BRA-002747. a Mid-part of raceme showing elliptic-oblong shaped and dorsally elongated uniseriated spikelets, attached by pedicel to the main axis. Some flowers are at anthesis and show extruded stigmas and dehiscent anthers. b Detail of the spikelet showing the superior $(S)$ and inferior $(I)$ floscules. A superior floscule comprises one hermaphrodite flower, identified by the pistil $(P)$ and anthers $(A)$, whereas the inferior floscule is only staminate $(A)$. c Spikelet showing superior $(S)$ and inferior (I) floscules, both hermaphrodite. Stigmas (arrowheads) at different stages of development (arrowheads) are observed. d Hermaphrodite flower showing stamens, filaments and anthers $(A)$ and the pistil with a unilocular, uniovulated ovary $(O v)$ within the stylodium 
nucellar cells with or without differentiating megaspore mother cells (MMC; Fig. 2a). Also at stage II, tetrads of megaspores were observed in some ovules, whereas others showed a single enlarged, uninucleated functional megaspore associated with a thin long dark stained approximately linear region corresponding to the three degenerating megaspores (Fig. 2b). No initial cells of aposporous embryo sacs were observed. At stage III, anatropically positioned ovules showed mostly enlarging selected megaspores surrounded by degenerating nucellar cells. At stage IV, enlarging embryo sacs of the Polygonum type containing the egg cell, two synergids, the bi-nucleated central cell and dividing antipodal cells were observed.

Approximately $93 \%$ of the superior flowers collected at anthesis initiation showed viable ovules containing embryo sacs of the Polygonum type, typically with polar nuclei and antipodal cells visible (Fig. 3c, d). Seven percent of flowers showed an undeveloped ovule or an aborted embryo sac. The egg cell, closely associated with the synergids, displayed a large cellular volume, a large nucleus (Fig. 3a, b) and contained numerous small vacuoles and vesicles. The central cell displayed a large vacuole and two polar nuclei (Fig. 3a, c), which represent the largest nuclei of the embryo sac. Antipodals were large and irregularly shaped cells with such distinctive morphological characteristics (Fig. 3a-d) as dividing nucleoli, surrounding dense nucleoplasm, and a dense cytoplasm that appears to be compressed by vacuoles near the nucleus.

No embryo sac of the Panicum type, which is present in Brachiaria apomicts, was observed in BRA-002747. The Panicum type is morphologically distinct from the Polygonum type due to the presence of only one polar nucleus within the central cell and the absence of antipodal cells.
Viable ovules displayed mostly a single embryo sac, although as many as $15 \%$ of them contained two, three (Fig. 4a, b) or four embryo sacs within the same ovule. When multiple embryo sacs did occur, they were morphologically characterized as conforming to the Polygonum type, which is typical in diploid sexual Brachiaria plants. These embryo sacs contained antipodal cells (Fig. 4a, b) and two polar nuclei within the central cell (Fig. 4c, d), in addition to two synergids and the egg cell. These embryo sacs were distributed in characteristic positions within the ovule, with one of them at the micropyle pole and the other(s) along the longitudinal axis of the ovule. A total of 12, 18 or 24 antipodal cells were observed whenever two, three or four embryo sacs, respectively, were observed within the same ovule.

Pollen development, viability and pollen-pistils interaction

Anthers classified as stage I and II (Araujo et al. 2000), with white color and $0.5-0.7 \mathrm{~mm}$ long, displayed developmental events corresponding to stages of microsporogenesis. The shorter anthers, classified as stage I, were in early microsporogenesis, showing a sporogenous mass composed of uniform, single-nucleated, polyhedral cells, corresponding to the pollen mother cells (PMC) that undergo meiosis (Fig. 5a) to form the microspores. The longer anthers at stage I and those at stage II exhibited later microsporogenesis characteristics, showing dyads and microspores tetrads (Fig. 5d, e) or large, regularly shaped, spherical microspores (Fig. 5f). A few microspores showed morphological alterations, such as smaller size and irregular shapes.

Developmental steps corresponding to microgametogenesis were detected in anthers classified as stage III and
Fig. 2 Brachiaria brizantha diploid sexual accession, BRA002747 longitudinal sections of developing ovules embedded in JB4. a Ovule at early megasporogenesis shows an enlarged megaspore mother cell within the nucellar tissue. b Late stage of megasporogenesis displaying part of the degenerating reduced megaspores (arrow) and the surviving chalazal megaspore. c Early megagametogenesis exhibiting the enlarged selected functional megaspore

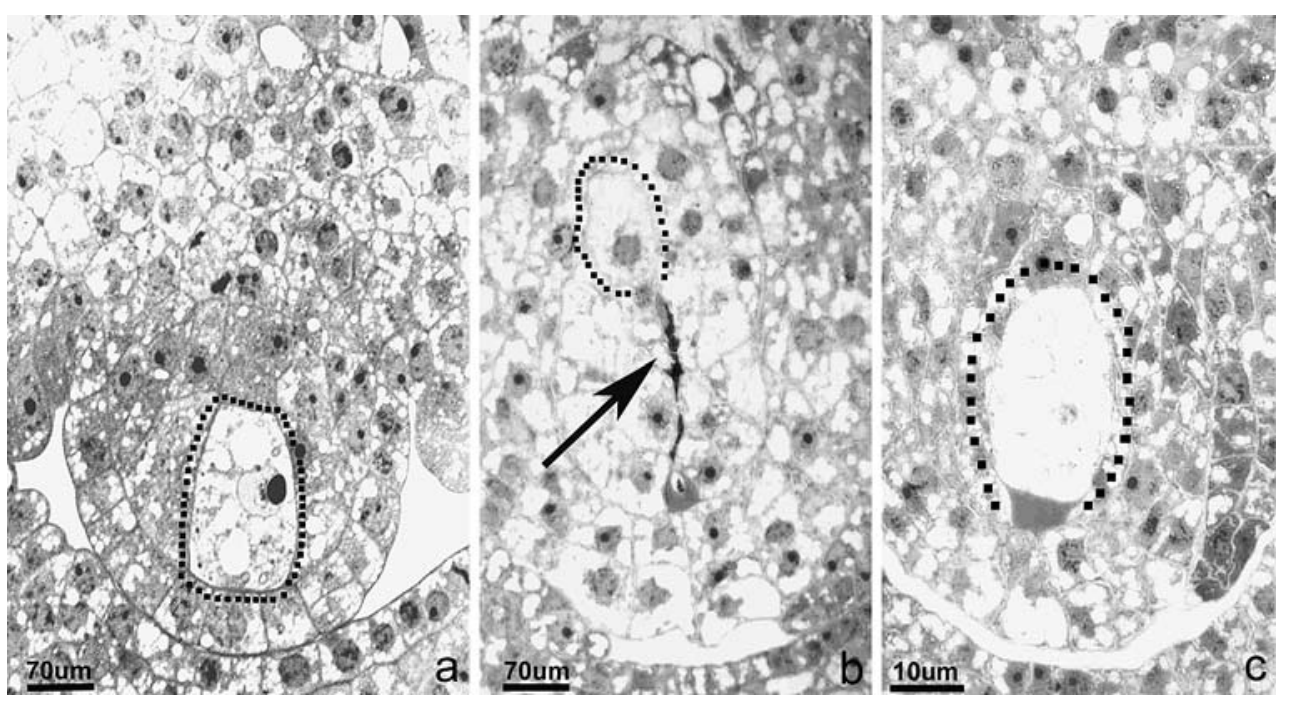


Fig. 3 Brachiaria brizantha diploid sexual accession, BRA002747 mature embryo sacs conforming to the Polygonum type. a, b JB4 longitudinal sections of embryo sacs displaying the egg cell $(E c)$, nucleus of one of the two synergids $(\mathrm{Sy})$ at the micropylar pole (My) of the ovule, the central cell $(C c)$ with two polar nuclei $(P n)$ and the chalazally situated antipodal cells $(A p)$. c, d Cleared pistils in DIC microscopy showing embryo sacs with c egg cell nucleus $(E c)$, d polar nuclei $(P n)$ and antipodal cells $(A p)$ with dividing nucleoli (arrows)

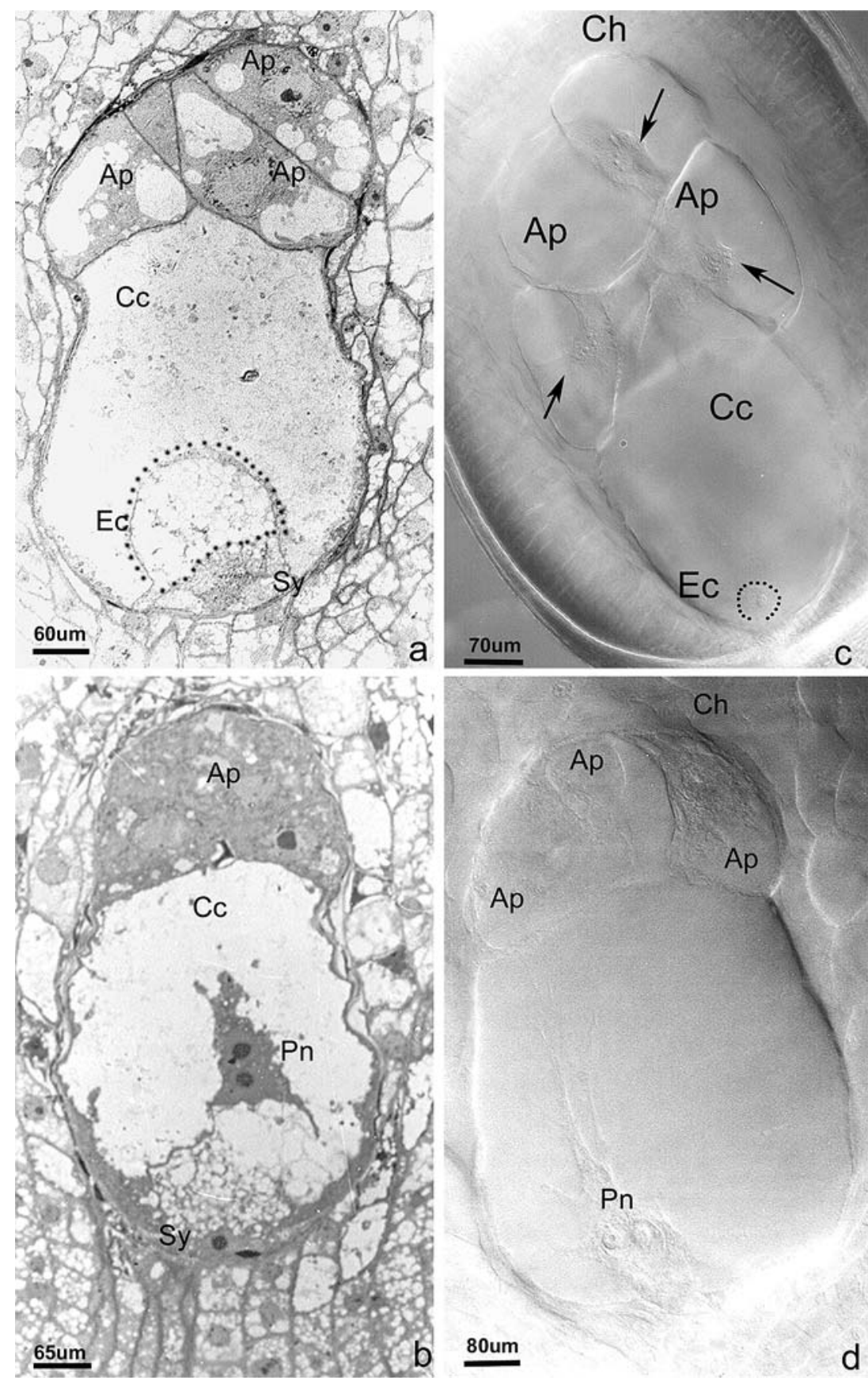

IV, which contained yellow anthers, 2.6-3.0 mm long. Shorter anthers at stage III exhibited early microgametogenesis characteristics, such as the presence of microspores preparing for mitosis and bicellular pollen (Fig. 5f), containing a generative cell (Fig. 5g). Longer anthers at stage III and shorter anthers at stage IV displayed stages indicative of late microgametogenesis, such as presence of bicellular pollen, which contains the generative and the larger vegetative cells. Other anthers at stage IV showed tricellular, monoporate, mature pollen grains with evident sperm cells.
Pollen viability of the superior flower as demonstrated by acetocarmine staining was estimated to be $84 \%$, and in the inferior flower was $80 \%$. This high viability was confirmed by the observation of in vivo pollen germination (Fig. 5h-j), although there were unavoidable losses of adhered pollen grains during this procedure. The remaining pollen grains could provide an overview of the process, and displayed no evidence of pollen tube rejection. Twenty five to 45 pollen grains were similarly distributed along the hairy portions of both branches of the stigma (Fig. 5i). One HAP, half of these adhered pollen grains were observed 
Fig. 4 Brachiaria brizantha diploid sexual accession, BRA002747 cleared ovules observed with DIC microscopy. a Ovule with three regularly distributed embryo sacs along the longitudinal axis of the ovule and antipodal cells $(A p)$ observed at the periphery of the embryo sacs. b Details of three embryo sacs conforming to the Polygonum type in another ovule. An egg cell is evident in the embryo sac at the micropyle $(M y)$, one synergid nucleus in the mid embryo sac and two polar nuclei in the central cell of the chalazal embryo sac. The inset contains the two polar nuclei in the central cell of the micropylar embryo sac.

c Another ovule with two embryo sacs of Polygonum type showing two polar nuclei (arrow) in each embryo sac and some of the six antipodal cells $(A p)$. d, e Higher magnification images of two embryo sacs of Polygonum type within the same ovule illustrating $\mathbf{d}$ the polar nuclei (arrow) and e the egg cells

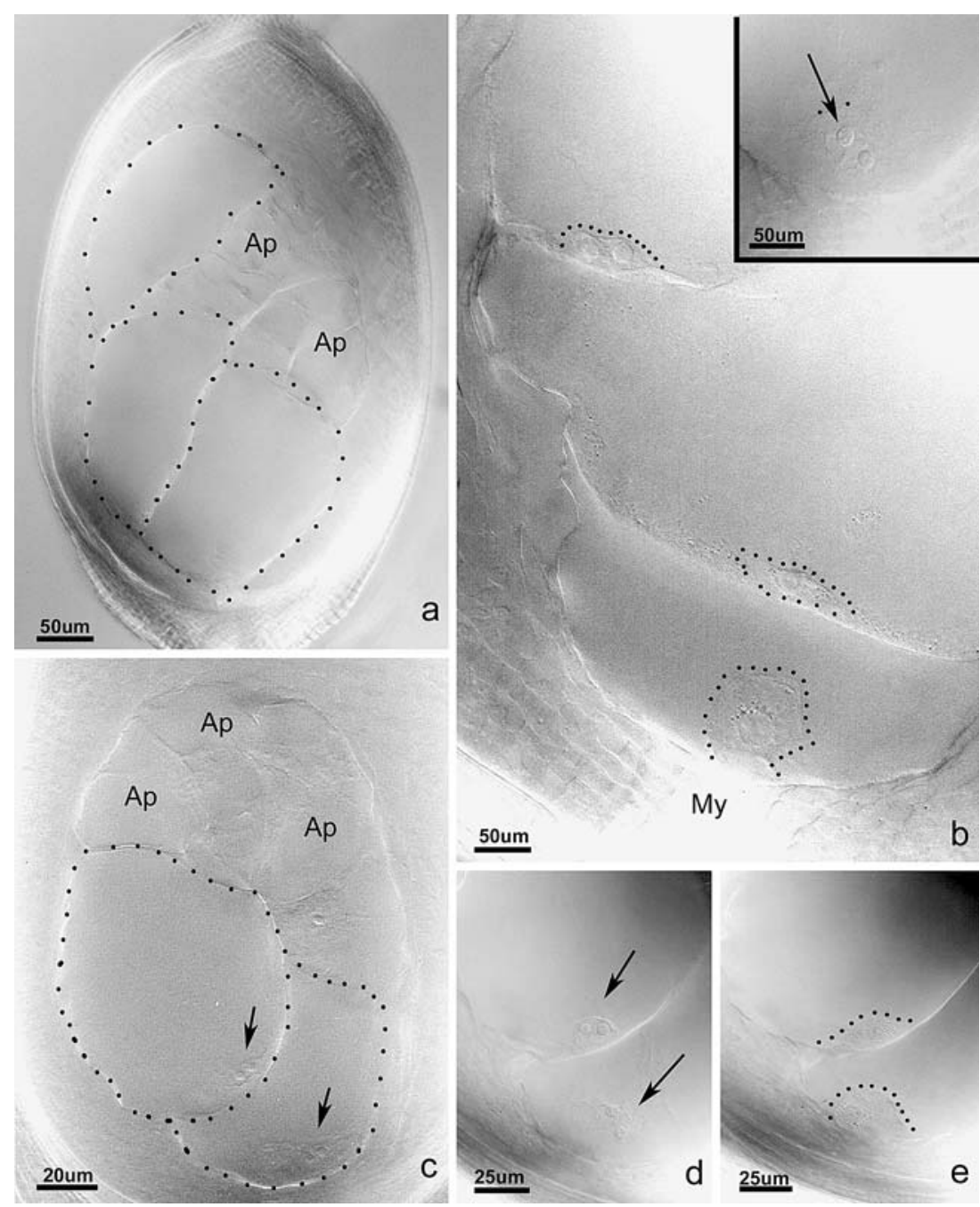

germinating and elongating on the stigma-style axis, with pollen viability confirmed by acetocarmine staining. Pollen tubes penetrated the stigmatic papillae and branches (Fig. 5j) and reached the style before 2 HAP. Few pollen tubes were observed in the style and growing towards the ovary. In a few pistils, 1-2 pollen tubes reached the ovary carpel (Fig. 5k). Between 6 and 8 HAP, a single pollen tube could often be observed at the micropyle pole and only rarely, two pollen tubes were present, one approaching from each side of the ovary. The extensive fluorescence of receptacles and stamen vestiges in the micropyle region prevented observation of pollen tube penetration into the embryo sac at 8 HAP.

\section{Embryogenesis and caryopsis abortion}

Analysis of caryopsis development was followed from anthesis initiation until 12 DAA, when caryopsis maturity is achieved (Table 1). The majority of pistils collected 1 DAA showed ovules with embryo sacs containing egg cells that were morphologically similar to those found at anthesis, suggesting that fertilization had not yet occurred. Developing caryopses with dividing embryo (Fig. 6b) and endosperm nuclei (Fig. 6c) could be observed in half of the viable pistils 2 DAA, indicating that fertilization takes place before 2 DAA. Observations using DIC microscopy showed that remaining viable pistils contained either unfertilized embryo sacs or zygotes that were undistinguishable from egg cells. The number of ovules containing embryo sacs at 2, 3, 4 and 5 DAA (10-20\%) presumably corresponds to unpollinated pistils. The majority of the caryopses harvested at 3 DAA contained multicellular embryos and endosperm nuclei (Fig. 6d). Antipodal cells could be observed in all embryo sacs containing an embryo and an endosperm until approximately 5 DAA, although indications of cell degeneration, such as intense vacuolization and disorganized nuclei, were noticed beginning at 2 DAA.

A gradual increase in the number of aborted caryopses was observed from 2 DAA until 7 DAA, with the 
Fig. 5 Developing and mature $B$. brizantha diploid sexual accession, BRA-002747 pollen. a Dividing, acetocarminestained pollen mother cells (PMC) obtained from an anther at stage I. b PMC showing two nuclei (arrowheads) after meiosis I. c Dyad with microspores separated by a cell wall (arrowhead).

d Longitudinal section of an anther at stage II embedded in Paraplast and showing degenerating tapetum $(\mathrm{Ta})$ and tetrads $(T)$ of microspores.

e Squashed anthers exhibiting microspore tetrads. f DIC image of an isolated bi-nucleated (arrows) pollen from an anther at stage II. g Isolated microspore from an anther at stage III with the vegetative $(V)$ cell and the single pore (arrow). h Longitudinal, semi-thin section of a self-pollinated stigma showing one selected pollen grain and its elongating pollen tube (arrowhead).

i Fluorescent microscopy of self-pollinated pistils collected $2 \mathrm{~h}$ after pollination with numerous pollen grains in the hairy portion of the stigma and elongating pollen tubes. $\mathbf{j}$ Detail of a selected pollen tube growing on the stigma of a selfpollinated pistil. $\mathbf{k}$ Pistil collected at $6 \mathrm{~h}$ after pollination showing pollen tube (arrow) within the ovary carpel

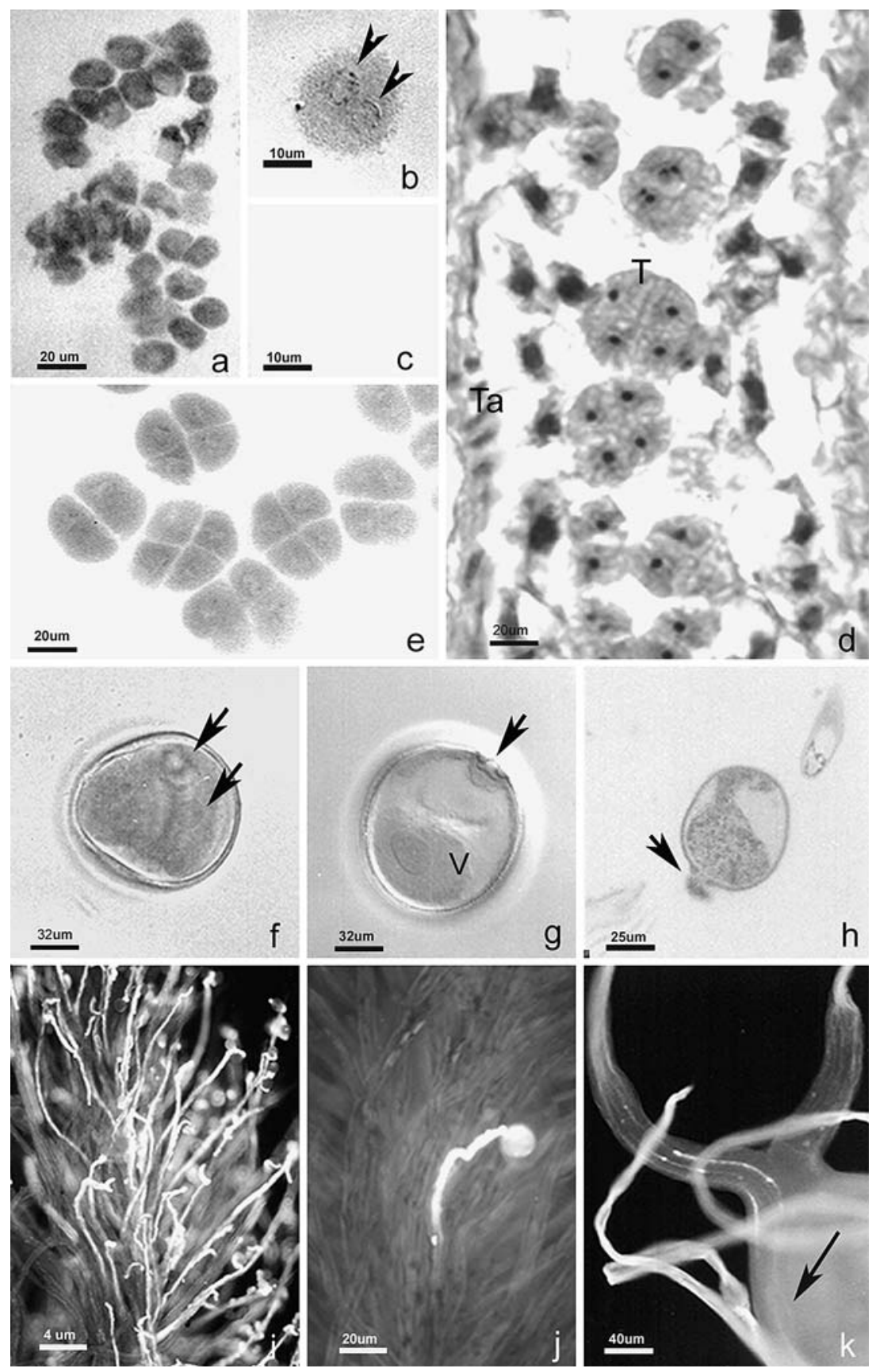

exception of 3 DAA. A high and linear rate of abortion was observed from 3 until 12 DAA. From 4 DAA onwards, viable developing caryopses contained multicellular embryos in which suspensors and endosperm cells could be observed (Fig. 6e). From 4 DAA onwards, viable developing caryopses contained multicellular embryos in which suspensors and endosperm cells could be observed (Fig. 6e). In other caryopses collected 3-7 DAA, the embryos could be distinguished as small structures in the micropylar position (Fig. 7a-c). Aborting caryopses appear to accumulate calcium oxalate crystal deposits within the carpel (Fig. 7d) or contain collapsed embryo sacs, ovules or ovaries. Viable caryopses harvested 7 DAA and later contained normally differentiating embryos (Fig. 7e).

Three embryo sacs displayed multicellular embryo with unfertilized polar nuclei while the other two embryo sacs displayed unfertilized egg cells surrounded by endosperm, suggesting that fertilization was incomplete. Multiple embryo sacs within one ovule were observed until 2 DAA. Of these approximately one-half contained embryo sacs that were morphologically similar to those at anthesis and the 
Table 1 Analysis of caryopsis development in BRA-002747 from the day of anthesis until 12 DAA

$A$ anthesis day, $D A A$ days after anthesis

Fig. 6 Caryopses development in $B$. brizantha diploid sexual accession, BRA-002747.

a Cleared pistil collected 1 day after anthesis initiation (DAA) viewed using DIC microscopy. Note egg cell at the micropylar pole (My) and antipodal cells $(A p)$. Inset shows detail of an egg cell of another embryo sac 1 DAA. b, c Higher magnification images of cleared caryopses collected 2 DAA showing dividing embryos. d Cleared caryopsis collected 3 DAA showing the embryo, endosperm nuclei (arrows) and antipodal cells $(A p)$. e Cleared caryopsis collected 6 DAA showing a globular embryo and part of the suspensor. The inset shows a longitudinal section of this caryopsis with embryo and endosperm cells

\begin{tabular}{|c|llllllllllllll|}
\hline $\begin{array}{c}\text { Number } \\
\text { of pistils with }\end{array}$ & A & 1 & 2 & 3 & 4 & 5 & 6 & 7 & 8 & 9 & 10 & 11 & 12 \\
\hline $\begin{array}{c}\text { Aborted/degenerated } \\
\text { ovule/ caryopsis } \\
\text { Embryo sac }\end{array}$ & 21 & 26 & 52 & 4 & 70 & 89 & 93 & 113 & 114 & 113 & 115 & 120 & 117 \\
$\begin{array}{c}\text { Multicellular embryo } \\
\text { and endosperm }\end{array}$ & 0 & 0 & 35 & 92 & 35 & 21 & 19 & 7 & 6 & 7 & 5 & 0 & 3 \\
\hline $\begin{array}{c}\text { Total } \\
\text { T- anthesis day; DAA - days after anthesis }\end{array}$ & 300 & 120 & 120 & 120 & 120 & 120 & 120 & 120 & 120 & 120 & 120 & 120 & 120 \\
\hline
\end{tabular}

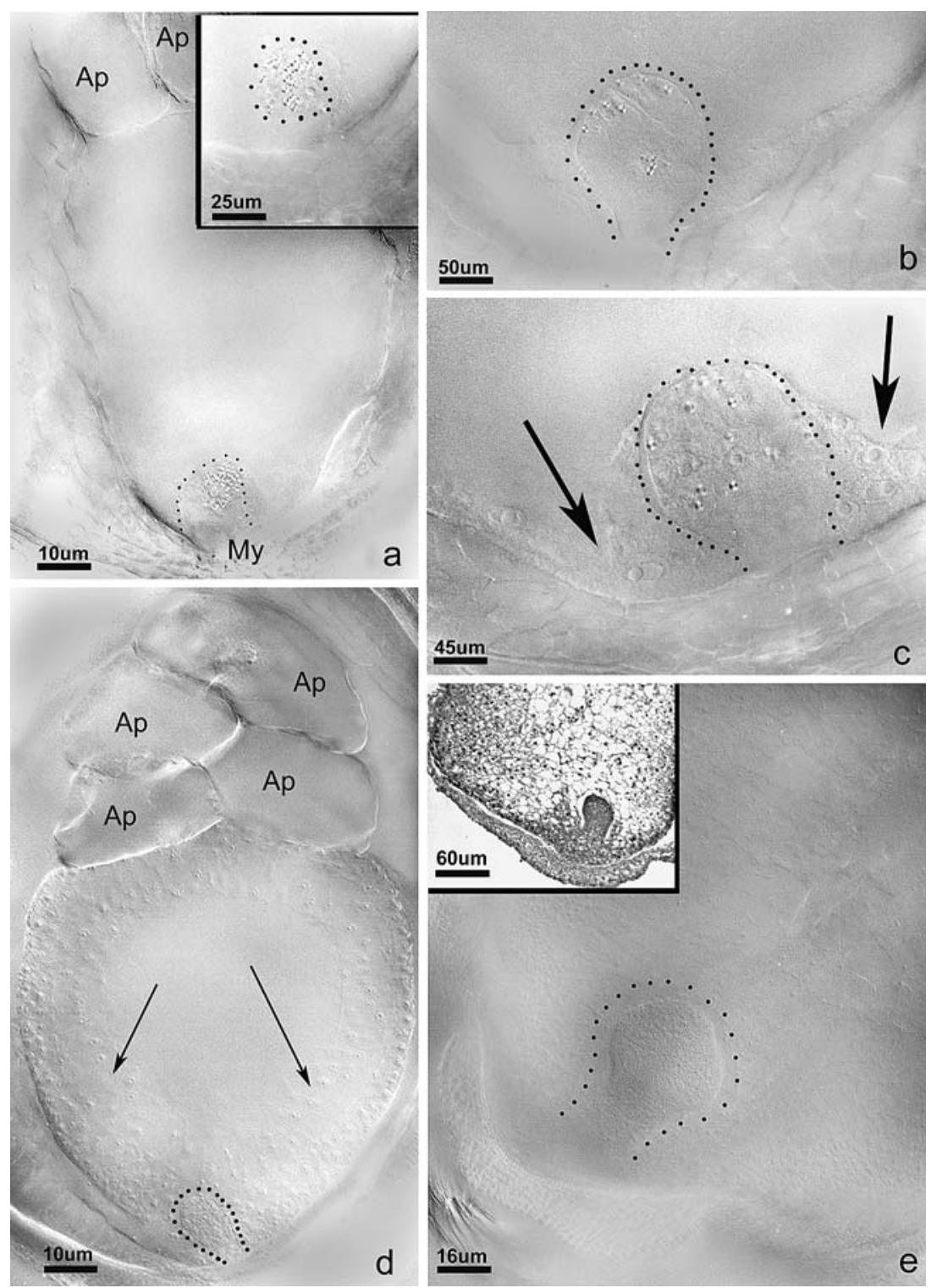

remainder contained embryos and endosperm in their micropyle pole. No multiple embryo sacs could be detected from 4 DAA onwards, nor were multiple embryos observed at caryopsis maturity.
Selfed seed set

A low number of seeds were obtained after controlled selfpollination $(2 \%)$ and open-pollination $(6 \%)$, which corre- 
sponded most likely to self-pollination. An evident decrease in the number of harvested seeds was observed from April until June.

\section{Discussion}

BRA-002747 was characterized as diploid $(2 n=2 x=18)$ by different methods (Carnahan and Hill 1958; Valle and Glienke 1991; Penteado et al. 2000), and its sexual mode of showing agamic complexes with sexual and apomicts counterparts (Savidan 2001). Although normal floral biology and reproductive behavior were confirmed by the presence of viable gametophytes and developing embryos and endosperm in the majority of the caryopses, limited seed production was observed because of high seed abortion.

Architecture, number and distribution of the flowers, anthesis pattern and gametophyte development were as those in the self-fertile cv. Marandu (Nunes 1984; Alves
Fig. 7 Cleared, developing caryopses of $B$. brizantha diploid sexual accession, BRA002747 , collected between 3 and 12 DAA. a-c Caryopses collected 3, 5, 7 DAA showing developing embryos and endosperm. d Pistil collected 5 DAA showing the embryo sac with antipodal cells $(A p)$ and deposits of oxalate crystals within the central cell $(C c)$, indicating abortion process. e Caryopsis collected at 12 DAA showing differentiating embryo (arrow)
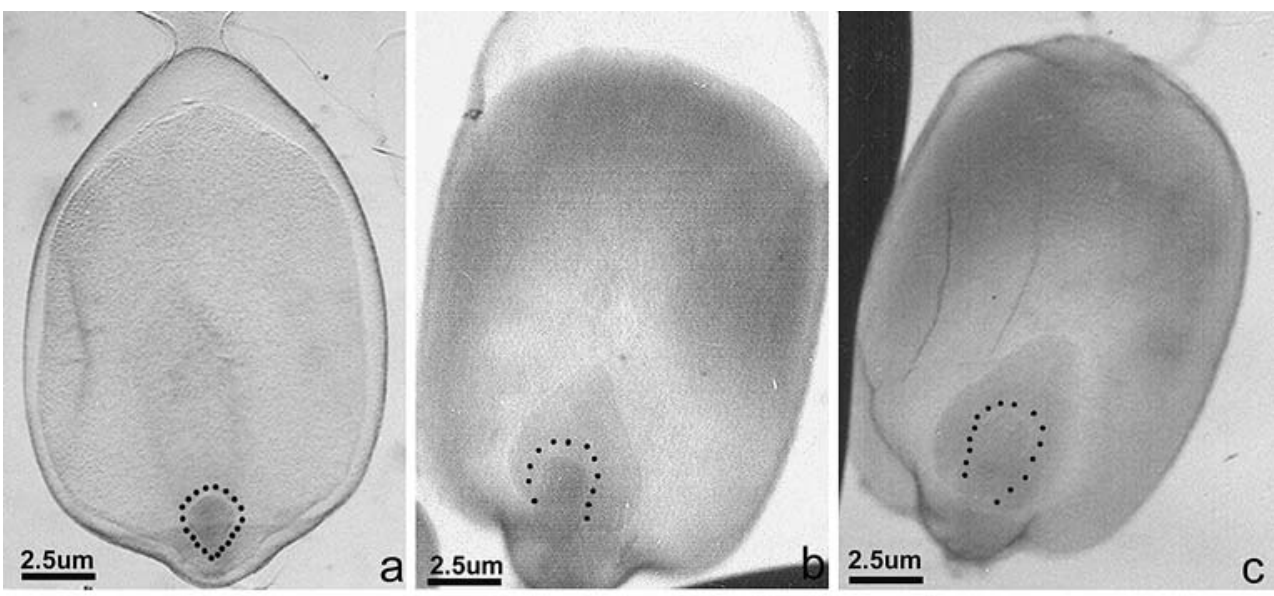

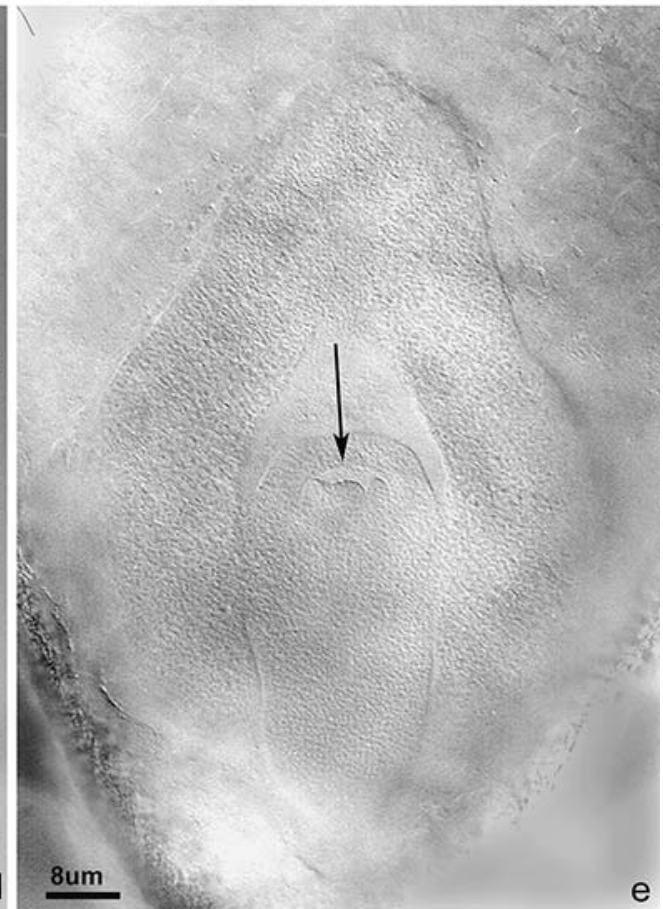

reproduction inferred by the presence of an embryo sac of the Polygonum type (Valle and Glienke 1991, Araujo et al., 2000, Araujo et al. 2005a), as in numerous Brachiaria species (Valle and Savidan 1996) and other grasses
2000) and in other sexual and apomictic Brachiaria accessions (Clayton and Renvoize 1986). Alterations observed in the female organs, such as the presence of two hermaphrodite flowers within the same spikelet and 
the presence of multiple embryo sacs of Polygonum type within the same ovule, are interesting aspects of the reproductive development that cannot be related to low fertility. The presence of a hermaphrodite flower in the inferior floscule instead of a staminate or a null flower is in disagreement with the taxonomic description for the subfamily, tribe and genus (Clayton and Renvoize 1986). The variation reported herein corroborates previous observations at Embrapa in Campo Grande, and Brasilia (Araujo and Falcão 2003a), suggesting that the presence of a hermaphrodite flower in the inferior floscule is not a characteristic associated with eventual biotic or abiotic factors, but a result of a floral atavistic phenomenon.

Previous studies of the BRA-002747 female gametophyte (Valle and Savidan 1996; Araujo et al. 2000), the $B$. decumbens diploid sexual accession (Dusi and Willemse 1999) and sexual hybrids of B. ruziziensis crossed with $B$. brizantha and $B$. decumbens species (Gobbe et al. 1982a, b; Ndikumana 1985; Lutts et al. 1991) indicated the presence of only one embryo sac of the Polygonum type in each ovule. However, multiple embryo sacs morphologically similar to the Polygonum type were detected in $15 \%$ of the pistils during the 2002 flowering season (Araujo and Falcão 2003b) and at similar frequency during the two subsequent years, suggesting its recurrent character. The reported absence of multiple embryo sacs in our previous analysis (Araujo et al. 2000) could be explained by morphological misinterpretation of the six enlarging antipodal cells and multiple developing embryo sacs in some ovules during megagametogenesis. In the current study, however, the presence of more than one embryo sac within many ovules was unmistakable in mature ovules collected at floral anthesis. In fully developed ovules, unlike earlier stages, multiple embryo sacs could be readily distinguished from the numerous antipodal cells.

Formation of more than one meiotically derived embryo sac within the same ovule is atypical, because usually only one nucellar cell differentiates into a megaspore mother cell (MMC) and it enters meiosis to form four reduced megaspores, of which only one reduced megaspore survives to form the embryo sac. In plants producing multiple embryo sacs, such as apomictic accessions of B. brizantha (Valle and Savidan 1996; Araujo et al. 2000; Araujo and Falcão 2004) embryo sacs are exclusively of the Panicum type (4-celled embryo sac) (Valle and Savidan 1996; Araujo et al. 2000). Prior morphological analysis has not revealed any evidence of apomixis in BRA-002747 (Araujo et al. 2000, 2005b, c). Changes in the megasporogenesis pathway, such as the development of multiple MMCs or an altered megaspore cell death program, could lead to the formation of two to four embryo sacs within the same ovule. Indeed, of Spurr- embedded ovules examined using light and transmission electron microscopes, ovules with two MMCs were reported in $2 \%$ and two surviving megaspores were reported in $7 \%$ (Araujo et al. 2005b, c). The reported frequency of multiple embryo sacs in BRA-00274 is 15\% (Araujo et al. $2005 \mathrm{~b}, \mathrm{c}$ ), which is higher than the frequency of ovules with two MMC or with two surviving megaspores. Thus, these alterations in the normal megasporogenesis program of meiotic lineages do not fully explain the abundance of multiple embryo sacs, and further analyses are now being carried out to determine the precise origin of the additional multiple embryo sacs.

The development of the microgametophyte in BRA002747 followed the normal sexual pattern of development of other flowering plants and produced abundant viable pollen grains throughout the flowering season, as observed in such other Brachiaria species as the sexual diploid and the induced tetraploid B. ruziziensis (Swenne et al. 1981; Gobbe et al. 1982a, b), in the tetraploid apomicts B. brizantha and B. decumbens (Lutts et al. 1994; Alves et al. 2001) and in hybrids of B. ruziziensis with B. Brizantha and B. decumbens (Lutts et al. 1994).

Open pollination in BRA-002747, however, whenever occurred, was most likely the result of self-pollination, given that in the surrounding area the only pollen donor with the same ploidy originated from another species with different flowering period. Under experimental conditions, the deposition and germination of pollen from other genera cannot be discounted although if this occurs, it presumably does so at a low rate.

Another potentially important factor that may account for reduced fruit/seed set is physiological self-incompatibility (SI) (Sage et al. 1999). SI consists of a genetically based system of self-recognition that reduces the frequency of successful self-fertilization and enhances heterosis. This mechanism is mostly recognized as a pre-zygotic barrier that may involve a failure of self-pollen to germinate on the stigma or impairs their later growth or both (Matton et al. 1994; De Nettancourt 1997).

The occurrence of SI through pollen tube/pistil reactions has been reported in sexual counterparts of such apomictic grasses as Parthenium argentatum, Zephyranthe, Eragrostis curvula, Panicum maximum and Brachiaria (Gustafsson 1946-1947; Stebbins 1950; Ngendahayo et al. 1988; Lutts et al. 1991), but does not appear to be the case in $B$. brizantha. In BRA-002747, self-pollen grains germinate, pollen tubes elongate and double fertilization occurs and thus seems unaffected by potential SI. Reductions in the number of pollen tubes successfully growing into the style in this accession were also observed in the apomictic, tetraploid, pseudogamous self-fertile cv. Marandu (Alves 2000; Alves et al. 2001). This reduction coincides with a restriction in the transmitting tract of the style. Reduction 
in the number of pollen tubes entering the lower style thus appears to be a feature of normal pollen tube elongation, and further, such reductions are evident in apomictic accessions of other Brachiaria as well (Ngendahayo et al. 1988). Earlier studies of the breeding system of the sexual diploid and the sexual-induced tetraploid $B$. ruziziensis suggest that these plants were weakly self-fertile, based on observation of pollen-pistil interactions resulting in variably self-fertile plants based on the seed set (reviewed by Ngendahayo et al. 1988; Lutts et al. 1991). Similarly, selffertility was demonstrated in the sexual counterpart of the apomictic Cenchrus ciliaris (buffelgrass) (Shafer et al. 2000)

Another important factor potentially causing reduced fruit/seed set is early-acting inbreeding depression (Sage et al. 1999). This rejection process causes abortion of homozygous offspring during embryo development due to the presence of deleterious recessive alleles (Charlesworth and Charlesworth 1987; Matton et al. 1994; Seavey and Carter 1996; Husband and Schenske 1996; De Nettancourt 1997). Early-acting inbreeding depression is generally characterized by: (1) a continuum of failure throughout the life cycle of the new generation and not by failure at a single stage; (2) variation in selfed individuals; (3) cross-compatibility among siblings or between progeny and parents due to the absence of SI genetic elements in the segregating alleles and (4) lack of success in embryo rescue due to the expression of homozygous lethal genes also under in vitro conditions (Seavey and Bawa 1986; Charlesworth and Charlesworth 1987; Husband and Schenske 1996; Sage and Sampson 2003). Since a gradual caryopsis rejection was observed in a continuum of developmental stages from 2 to 7 DAA, with the exception of 3 DAA, which was considered as an inconsistency, and since caryopses require 12 days to mature, seed abortion may be explained simply in the context of early-acting inbreeding depression. This and other evidence of inbreeding depression action, as well as embryo malformation could not be tested, however, in this accession because no suitable population or progeny is available. The embryo rescue technique in Brachiaria is only successful for embryos older than 7 days (RodriguesOtubo et al. 2000) and only few developing caryopses could be gathered.

Interestingly, tetraploid sexual $B$. brizantha are selffertile plants (Araujo et al. 2005a), different from the accession studied here, BRA-002747, from which they originated. Similarly, induced tetraploid Paspalum hexastachyum were described as self-fertile plants (Quarin and Hanna 1980), and the polyploid accessions of B. ruziziensis are regarded as being partially self-fertile (reviewed by Ngendahayo et al. 1988; Lutts et al. 1991), suggesting that some polyploids within agamic complexes can overcome self-incompatibility. The present data show that seed set in BRA-002747 is low and, in contrast with previous reports on apomictic grasses, including Brachiaria (Gustafsson 1946-1947; Stebbins 1950; Ngendahayo et al. 1988; Lutts et al. 1991), it is not caused by pollen tube/pistil rejection but by a failure in caryopsis completion in a continuum of developmental stages, typical of inbreeding depression.

\section{References}

Alves ER (2000) Aspectos da Reprodução em Brachiaria brizantha cv. Marandu. Master Thesis, Universidade de Brasília, Brasília, Brazil

Alves ER, Carneiro VTC, Araujo ACG (2001) Direct evidence of pseudogamy in an apomictic Brachiaria brizantha (Poaceae). Sex Plant Reprod 14:207-212

Alves E, Carneiro VTC, Dusi DMA (2007) In situ localization of three cDNA sequences associated to the later stages of aposporic embryo sac development of Brachiaria brizantha. Protoplasma (in press)

Araujo ACG, Falcão R (2003a) Característica floral atípica em Brachiaria brizantha (Poaceae). Com Técnico 82. Brasília, Brazil: Embrapa: Recursos Genéticos e Biotecnologia, 5 pp

Araujo ACG, Falcão R (2003b) Observação de múltiplos sacos embrionários em ovário de plantas do acesso sexual de Brachiaria brizantha (Poaceae). Bol Pesq Desenv 40. Brasília, Brazil: Embrapa: Recursos Genéticos e Biotecnologia, 16 pp

Araujo ACG, Falcão R (2004) Identificação de acessos de Brachiaria com interesse ao estudo da apomixia facultativa. Bol Pesq Desenv, 74. Brasília, Brazil: Embrapa: Recursos Genéticos e Biotecnologia, $29 \mathrm{pp}$

Araujo ACG, Mukhambetzhanov S, Pozzobon MT, Santana EF, Carneiro VTC (2000) Female gametophyte development in apomictic and sexual Brachiaria brizantha (Poaceae). Rev Cytol Biol Veg Le Botaniste XXIII:13-28

Araujo ACG, Nóbrega JM, Pozzobon MT, Carneiro VTC (2005a) Evidence of sexuality in induced tetraploids of Brachiaria brizantha (Poaceae). Euphytica 144:39-50

Araujo ACG, Falcão R, Carneiro VTC (2005b) Towards the origin of the multiple embryo sacs in the diploid, sexual accession of Brachiaria brizantha (Poaceae). Braz J Morphol Sci Supp 264265

Araujo ACG, Falcão R, Carneiro VTC (2005c) Altered female gametogenesis in the diploid sexual accession of Brachiaria brizantha (Poaceae). Documentos, 139. Brasília, Brazil Embrapa Recursos Genéticos e Biotecnologia, Brazil

Asker SE, Jerling L (1992) Apomixis in Plants. CRC Press, Boca Raton

Baumann U, Juttner J, Bian X, Langride P (2000) Self-incompatibility in the grasses. Ann Bot 85(Supp A):203-209

Bush EJ, Barret SCH (1993) Genetics of mine invasions by Deschampsia cespitosa (Poaceae). Can J Bot 71:1336-1348

Carnahan HL, Hill HD (1958) Apomixis in the Gramineae: Panicoideae. Am J Bot 54:253-253

Charlesworth D, Charlesworth B (1987) Inbreeding depression and its evolutionary consequences. Ann Rev Ecol Syst 18:237-268

Clayton WD, Renvoize SA (1986) Genera Graminum Grasses of the world. Additional Scenes, XIII Her Majesty's Stationery Office, Royal Botanic Gardens, Kew. London Kew Bulletin

De Nettancourt D (1997) Incompatibility in angiosperms. Sex Plant Reprod 10:185-199 
Dusi DMA, Willemse MTM (1999) Apomixis in Brachiaria decumbens Stapf: gametophytic development and reproductive calendar. Acta Biol Cracov Soc Bot 41:151-162

East EM (1940) The distribution of self-sterility in flowering plants. Proc Am Philos Soc 82:449-518

Fukui K, Nakayama S (1996) Plant chromosomes: laboratory methods. CRC Press, London

Gibbs P, Bianchi MB, Taroda Ranga N (2004) Effects of self-, chase and mixed self/cross-pollinations on pistil longevity and fruit set in Ceiba species (Bombacaceae) with late-acting self-incompatibility. Ann Bot 94:305-310

Gobbe J, Longly B, Louant BP (1982a) Calendrier des sporogénèse et gametogénèse femelles chez le diploïde et le tétraploïde induit de Brachiaria ruziziensis (Graminée). Can J Bot 60:2032-2036

Gobbe J, Swenne A, Louant BP (1982b) Diploïdes naturels et autotetraploïdes induits chez Brachiaria ruziziensis Germain et Evrard: critères d' identification. Agro Tropic 36:339-346

Gustafsson A (1946-1947) Apomixis in higher plants. Parts I, II, II. Lunds Universitets Arssk. N.F. pp 42-43:1-370

Husband BC, Schenske DW (1996) Evolution of the magnitude and timing of inbreeding depression in plants. Evolution 50:54-70

Keller-Grein G, Maass BL, Hanson J (1996) Natural variation in Brachiaria and existing germplasm collections. In: Miles JW, Maass BL, Valle CB do (eds) Brachiaria: biology, agronomy, and improvement. CIAT, Colombia, pp 16-42

Lundqvist A (1964) The nature of the two-loci incompatibility system in grasses. IV. Interaction between the loci relation to pseudocompatibility in Festuca pratensis Huds. Hereditas 52:221-234

Lutts S, Ndikumana J, Louant BP (1991) Fertility of Brachiaria ruziziensis in interspecific crosses with Brachiaria decumbens and Brachiaria brizantha: meiotic behavior, pollen viability and seed set. Euphytica 57:267-274

Lutts S, Ndikumana J, Louant BP (1994) Male and female sporogenesis and gametogenesis in apomictic Brachiaria brizantha, Brachiaria decumbens and F1 hybrids with sexual colchicine induced tetraploid Brachiaria ruziziensis. Euphytica 78:19-25

Martin FM (1959) Staining and observing pollen tubes in the style by means of fluorescence. Stain Technol 34:436-437

Matton DP, Nass N, Clarke AE, Newbigin E (1994) Self-incompatibility: how plants avoid illegitimate offspring. Proc Natl Acad Sci USA 91:1992-1997

Mendes-Bonato AB, Pagliarini MS, Forli F, Valle CB do, Penteado MIO (2002) Chromosome numbers and microsporogenesis in Brachiaria brizantha. Euphytica 125:419-425

Ndikumana J (1985) Étude de l'hibridation entre espèces apomictiques et sexuées dans le genre Brachiaria. $\mathrm{PhD}$ Thesis, Université de Louvain, Louvain-la-Neuve, Belgium

Ngendahayo M, Coppens d'Eeckenbrugge, Loaunt BP (1988) Selfincompatibility studies in Brachiaria ruziziensis Germain et Evrard, Brachiaria decumbens Stapf and Brachiaria brizantha (Hoschst) Stapf and their interspecific hybrids. Phytomorphology $38: 47-51$

Nunes SG (1984) Brachiaria brizantha cv. Marandu Documentos 21. Embrapa-CNPGC, Campo Grande, MS, Brazil

Penteado MI de O, Santos ACM dos, Rodrigues JF, Valle CB do, Seixas MAC, Esteves A (2000) Determinação de ploidia e quantidade de DNA em diferentes espécies do gênero Brachiaria. Bol Pesq 11. Embrapa-CNPGC, Campo Grande, MS, Brazil, pp 31
Pinheiro AA, Pozzobon MT, Valle CB do, Penteado MIO, Carneiro VTC (2000) Duplication of the chromosome number of diploid Brachiaria brizantha plants, using colchicine. Plant Cell Rep 19:274-278

Quarin CL, Hanna WW (1980) Effect of three ploidy levels on meiosis and mode of reproduction in Paspalum hexastachyum. Crop Sci 20:69-75

Renvoize SA, Clayton WD, Kabuye CHS (1996) Morphology, taxonomy and natural distribution of Brachiaria (Trin.) Griseb. In: Miles JW, Maass BL, Valle CB do (eds) Brachiaria: biology, agronomy, and improvement. CIAT, Colombia, pp 1-15

Rodrigues-Otubo BM, Penteado MI de O, Valle CB do (2000) Embryo rescue of interspecific hybrids of Brachiaria spp. Plant Cell Tissue Organ Cult 61:175-182

Rodrigues JCM, Cabral GB, Dusi DMA, Mello LV, Rigden D, Carneiro VTC (2003) Identification of differentially expressed cDNA sequences in ovaries of sexual and apomictic plants of Brachiaria brizantha. Plant Mol Biol 53:745-757

Sage TL, Sampson FB (2003) Evidence for ovarian self-incompatibility as a cause of self-sterility in the relictual woody angiosperm Pseudowintera axillaris (Winteraceae). Ann Bot 91:807-816

Sage TL, Strumas F, Cole WW, Barrett SCH (1999) Differential ovule development following self- and cross-pollination: the basis of self-sterility in Narcissus triandrus (Amaryllidaceae). Am J Bot 86:855-870

Savidan Y (2001) Transfer of apomixis through wide crosses. In: Savidan Y, Carman JG, Dresselhaus T (eds) The flowering of apomixis: from mechanisms to genetic engineering. CIMMYT, IRD, European Commission DG VI (FAIR), Mexico, DF, pp 153-166

Seavey SR, Bawa KS (1986) Late acting self-incompatibility in angiosperms. Bot Rev 52:195-219

Seavey SR, Carter SK (1996) Ovule fates in Epilobium obcordatum (Onagraceae). Am J Bot 83:316-325

Shafer GS, Burson BL, Hussey MA (2000) Stigma receptivity and seed set in protogynous buffelgrass. Crop Sci 40:391-397

Stebbins GL (1950) Variation and evolution in plants. Columbia University Press, New York

Swenne A, Louant BP, Dujardin M (1981) Induction par la colchicine de formes autotetraploïdes chez Brachiaria ruziziensis Germain et Evrard (Graminée). Agron Trop 36:134-141

Valle CB do (1986) Cytology, mode of reproduction and forage quality of selected species of Brachiaria Griseb. PhD Thesis, University of Wisconsin, Madison, USA

Valle CB do (1990) Coleção de germoplasma de espécies de Brachiaria no CIAT: estudos básicos visando ao melhoramento genético. Documentos Embrapa-CNPGC, Campo Grande, MS, Brazil

Valle CB do, Glienke C (1991) New sexual accessions in Brachiaria. Apo Newsl 3:11-13

Valle CB do, Savidan Y (1996) Genetics, cytogenetics, and reproductive biology of Brachiaria. In: Miles JW, Maass BL, Valle CB do (eds) Brachiaria: biology, agronomy, and improvement. CIAT, Colombia, pp 147-163

Young BA, Sherwood RT, Bashaw EC (1979) Cleared-pistil and thick-sectioning techniques for detecting aposporous apomixis in grasses. Can J Bot 57:1668-1672 